\title{
Alternative tourism through product and service networks for the development of Santiago, of the Cabo del Este Region of the Municipality of Los Cabos
}

\section{El turismo alternativo a través de redes de productos y servicios para el desarrollo de Santiago, de la Región de Cabo del Este del Municipio de Los Cabos}

\author{
ROBLES-ARIAS, Isela Margarita*†, FLORES-MEZA, Jhony Ramon, SANDOVAL-GARCIA, Brian \\ and VALDEZ-GUERRERO, Raquel
}

Tecnológico Nacional De México/ Instituto Tecnológico De La Paz, La Paz, Baja California Sur, Boulevard Forjadores De Baja California Sur 4720, CP: 23080

ID $1^{\text {st }}$ Author: Isela Margarita, Robles-Arias / ORC ID: 0000-0001-5164-156X, CVU CONACYT ID: 404596

ID 1 ${ }^{\text {st }}$ Coauthor: Jhony Ramon, Flores-Meza / ORC ID: 0000-0001-8250-391X, CVU CONACYT ID: 1097533

ID $2^{\text {nd }}$ Coauthor: Brian, Sandoval-Garcia / ORC ID: 0000-0002-1558-987X, CVU CONACYT ID: 1097584

ID $3^{\text {rd }}$ Coauthor: Raquel, Valdez-Guerrero / ORC ID: 0000-0003-0972-0189, CVU CONACYT ID: 407004

\section{Abstract}

A strategic plan is presented, it includes strategies that facilitate the structuring and implementation of a network of products and services in the population of Santiago, B.C.S. to achieve the economic reactivation of the community. In the development of this project, documentary and field research was used to obtain information related to this population, its inhabitants, its activities, its traditions and customs, etc. They went to the area to have a group interview with the authorities and inhabitants of the place to carry out the definition of the project and establish the necessary commitments with them. Subsequently, zoning activities, inventory of flora, fauna, gastronomy and tourist attractions of the area were carried out, the results of which were extremely important and a key piece for this research. Both the general and specific objectives were fully met, resulting in the design of strategies that, if implemented, will allow this population to become one of the preferred tourist areas for both national and foreign visitors, generating benefits mainly for its inhabitants.

Strategic planning, Service network, Alternative tourism

\begin{abstract}
Resumen
Se presenta un plan estratégico, incluye estrategias que facilitan la estructuración e implementación de una red de productos y servicios en la población de Santiago, B.C.S. para lograr la reactivación económica de la comunidad. En el desarrollo de este proyecto se utilizó la investigación documental y de campo para la obtención de información relacionada a esta población, sus habitantes, sus actividades, sus tradiciones y costumbres, etc. Se acudió a la zona para tener una entrevista grupal con las autoridades y habitantes del lugar para llevar a cabo la definición del proyecto y establecer los compromisos necesarios con ellos. Posteriormente se realizaron actividades de zonificación, levantamiento de inventarios de flora, fauna, gastronomía y atractivos turísticos de la zona, cuyos resultados fueron sumamente importantes y pieza clave para esta investigación. Tanto el objetivo general como los específicos fueron cumplidos en su totalidad dando como resultado el diseño de estrategias que de ser implementadas permitirán que esta población pueda convertirse en una de las zonas turísticas preferidas por visitantes tanto nacionales como extranjeros, generando beneficios principalmente para sus habitantes.
\end{abstract}

Planeación estratégica, Red de servicios, Turismo alternativo

Citation: ROBLES-ARIAS, Isela Margarita, FLORES-MEZA, Jhony Ramon, SANDOVAL-GARCIA, Brian and VALDEZGUERRERO, Raquel. Alternative tourism through product and service networks for the development of Santiago, of the Cabo del Este Region of the Municipality of Los Cabos. RINOE Journal- General Economics. 2020. 4-6:1-15

$\dagger$ Researcher contributing first author. 


\section{Introduction}

Alternative tourism today has become a very important factor for the economy of the State of Baja California Sur, derived from the characteristics that the region has in natural attractions have positioned the same State in one of the main places to visit and carry out purely tourist activities. Every year statistical records (anonymous, 2019) are made where the economic impact and growth that occurs in tourism can be appreciated, this generates greater economic income and in turn more sources of employment.

Santiago is a small community belonging to the Municipality of Los Cabos, in the Mexican state of Baja California Sur. It is located on the side of Federal Highway 1 in Mexico, $135 \mathrm{~km}$ south of La Paz and about 45 kilometers north of San José del Cabo. Like Todos Santos it is almost directly above the Tropic of Cancer. It is located at the coordinates $23^{\circ} 28.747 \mathrm{~N}^{\prime} 109^{\circ}$ $42.748^{\prime} \mathrm{W}$ at an approximate altitude of 132 meters above sea level. It has a population of 783 inhabitants according to the data provided by INEGI (National Institute of Statistics and Geography, 2020)

The town of Santiago is characterized by its agricultural, livestock and tourist services activities, the latter today can be one of the main engines of the town, it has a great impact and a strong mobilization between the different places of which many of them They are natural as they are: waterfalls, hot springs, lagoons, and some others in which the hand of man has intervened as they are; the town, the parish, archaeological sites and the production of saddlery, carpentry, as well as the production of cheese, crush and regional sweets with seasonal fruit (mango, guava, papaya, and grapefruit candy among others.

Other types of activities are carried out such as purposeful hiking, flora and fauna observation, and photographic safari.However, most service providers do not have the necessary measures to be able to carry out a quality service, which causes the tourist to ignore and stop visiting these areas due to the lack of a development plan.
The purpose of carrying out this research consisted of knowing the availability of the people of the Santiago community to identify areas of opportunity for the development of alternative tourism through a network of products and services that help boost the economy of the region. In the same way, structure a strategic plan that the community can use to solve the low economic development of the area.

For the development of the research, a quantitative study, a field research and documentary research were carried out, in addition to the application of different tools for the analysis of information such as SWOT, CFKE and Ishikawa diagram, which helped to design the strategies that served to develop proposals for improvement and recommendations which will have a positive impact for the benefit of community service providers.

\section{Research Objectives}

\section{General:}

Design a strategic plan in order to promote the tourist and economic development of the Santiago community in the municipality of Los Cabos, through the collaboration of the inhabitants of the place in a network of services.

Specific:

1. Identify areas of opportunity for the development of alternative tourism; rural, ecological and adventure tourism.

2. Know the disposition of the inhabitants of Santiago to form a network of products and services to develop and promote the economy of the region.

3. Integrate a strategic plan to promote the economic development of the region as a tourist area.

\section{Methodology to be developed}

In this section, a more specific and personalized methodology proposal has been developed for the development of this research, based on the combination of the methodology of two models. 
In other words, it is about the fusion of the "Alternative services planning model (Casal, 2002)" applicable for the creation and representation of the alternative services network, it is based mainly on the different types of services that make up the basic service package. of a company that provides tourist services. and the "Model of the strategic plan (Chiavenato, 2011). Which is based on identifying potential resources, aligning skills, recognizing strengths and weaknesses, and establishing the set of integrated measures that will be applied to ensure that the organization achieves the planned results. But it must be taken into account that this will only reach its maximum effectiveness when all the people who make it up as a whole, accept it, attend to it and apply it..

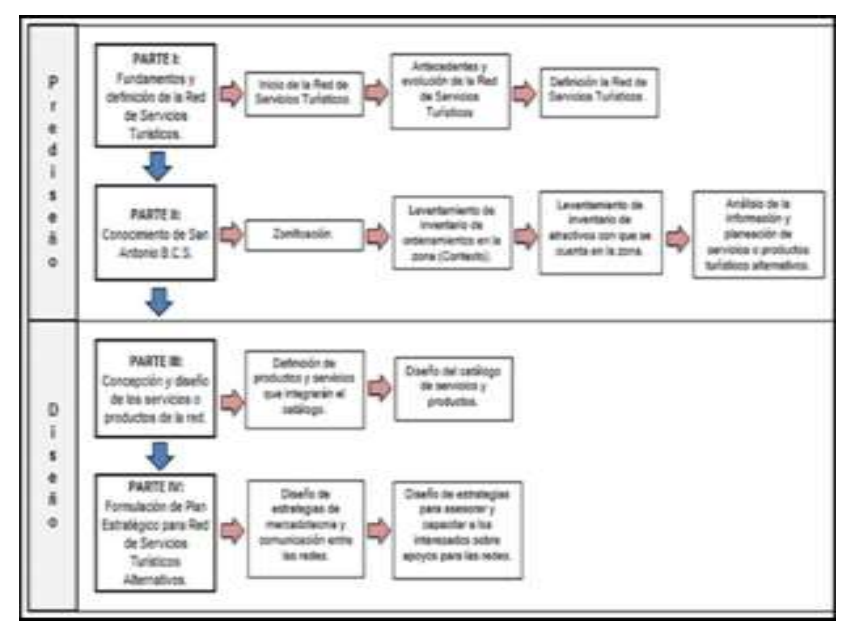

Figure 1 Strategic Research Model

Source: Own Elaboration

\section{Investigation Development}

For the realization of this project, the type of documentary and field research was carried out, implementing a mixed research approach, which is integrated by qualitative and quantitative methods, so that the information that was collected was significant, showing a broader perspective and insight into the conditions of the village.

Once the general idea of the project was designed, as mentioned previously, the area was visited to have a group interview with the authorities and inhabitants of the place to carry out the definition of the project and establish the necessary commitments to carry out carry out the various activities. Several instruments were designed and applied such as:
1. With observation, inventories were collected to determine the amount of tourist places, flora, fauna, gastronomy and architecture and tourist attractions that the community has.

2. The survey to residents of Santiago was in order to detect those interested in participating, as well as to know the disposition and openness of the population for the development of their community through the implementation of a network of products and services that would be focused on the positioning of the region in tourism matters,.,

To carry out this research, two populations were considered, in the first instance the inhabitants of Santiago who represent 783 according to data from (National Institute of Statistics and Geography, 2020); Simple random sampling was used with a margin of error of $10 \%$ and a confidence level of $99 \%$, which yielded a sample of 138 .

$n=\frac{\frac{z^{2} \times p(1-p)}{e^{2}}}{1+\left(\frac{z^{2} \times p(1-p)}{e^{2} N}\right)}$

Taken from (Badii, 2011)

$\mathrm{N}=$ population size $=783$

$\mathrm{p}=$ confidence level $=0.99$

$\mathrm{e}=$ margin of error $=0.08$

$\mathrm{z}=99 \% \mathrm{z}$ score $=2.58$

$\mathrm{n}=$ sample $=198$

The survey instrument was designed in Google forms so it required having internet coverage with devices such as cell phones and computers, it was applied at different strategic points in the community where the influx of people was greater. 198 people were surveyed.

\section{Information processing.}

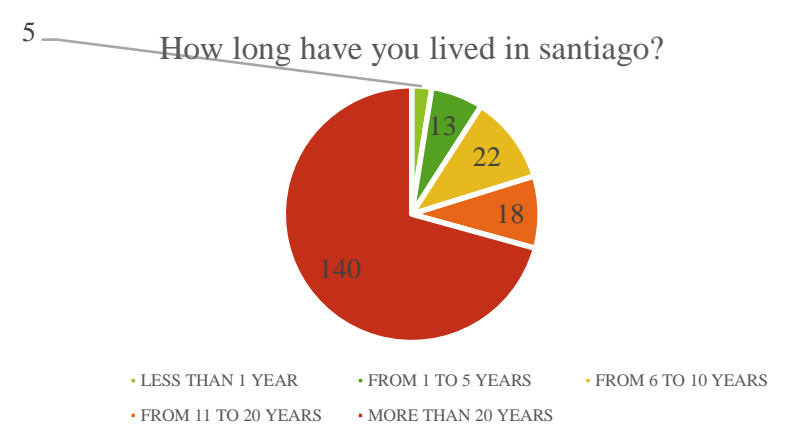

Graphi 1 Time living in the community

ROBLES-ARIAS, Isela Margarita, FLORES-MEZA, Jhony Ramon, SANDOVAL-GARCIA, Brian and VALDEZ-GUERRERO, Raquel. Alternative tourism through product and service networks for the development of Santiago, of the Cabo del Este Region of the Municipality of Los Cabos. RINOE Journal- General Economics. 2020 
The graph shows that $70 \%$ have lived in Santiago for more than 20 years

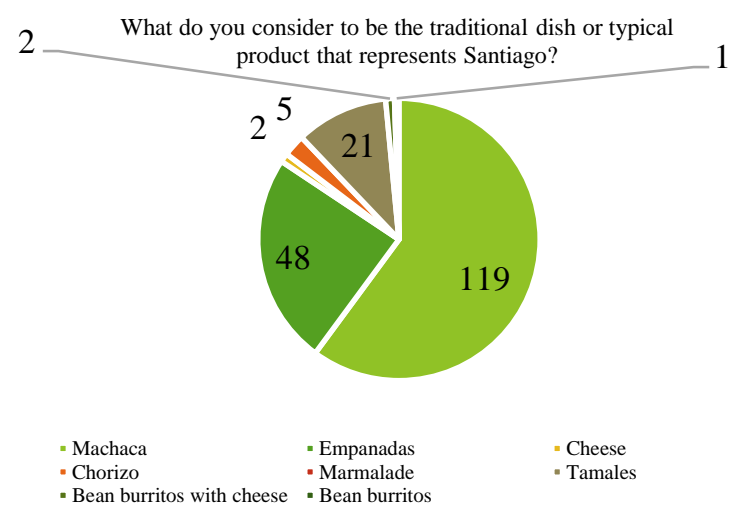

Graphic 2 Traditional Santiago dish

The graph shows that $60.1 \%$ of those surveyed responded that machaca is the typical dish that the Santiago community represents, while $24.2 \%$ responded that empanadas are the typical dish of said community, $10.6 \%$ responded that they are tamales, $2.5 \%$ responded that cheese is the typical product, while the remaining $2 \%$ responded that it is chorizo.

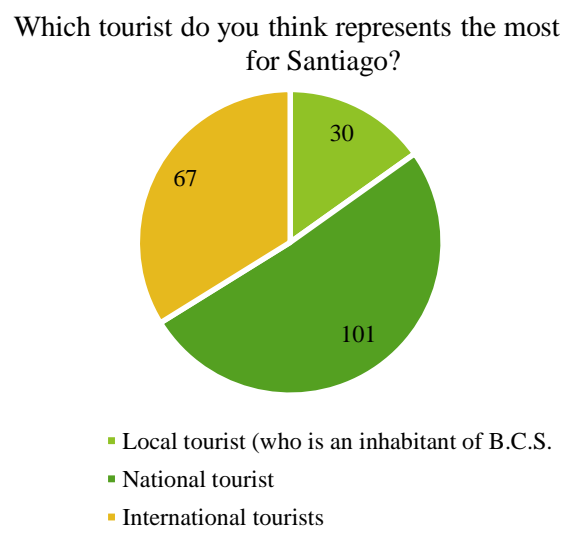

Graphic 3 What tourism represents more profit for Santiago

The graph shows us that the tourism that leaves the most profit is $51 \%$ who indicate that it is the national tourist, $33 \%$ indicate that it is the international one and finally $15 \%$ the local tourism

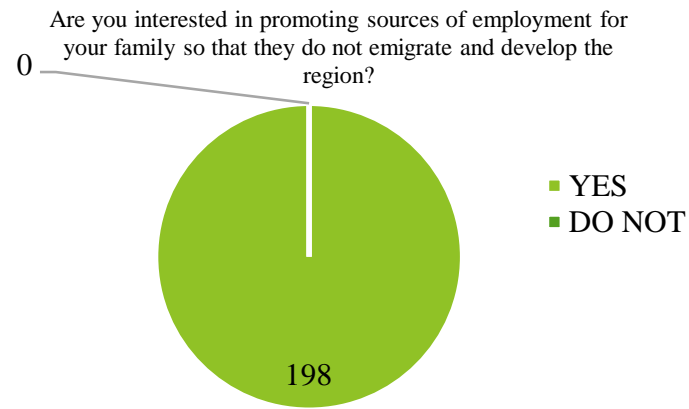

Graphic 4 Interest of the inhabitant in promoting sources of employment and development
The graph shows us that $100 \%$ are interested in participating

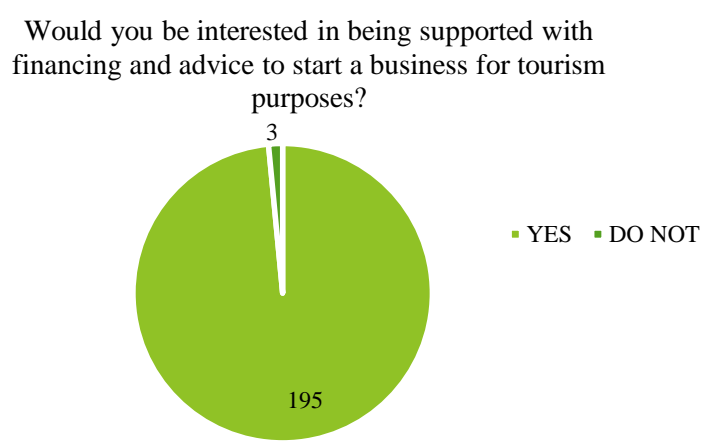

Graphic 5 Interest in obtaining support for financing

The graph shows us that $98 \%$ are interested in receiving advice and financing.

Select the products that you could offer to the tourist visiting Santiago

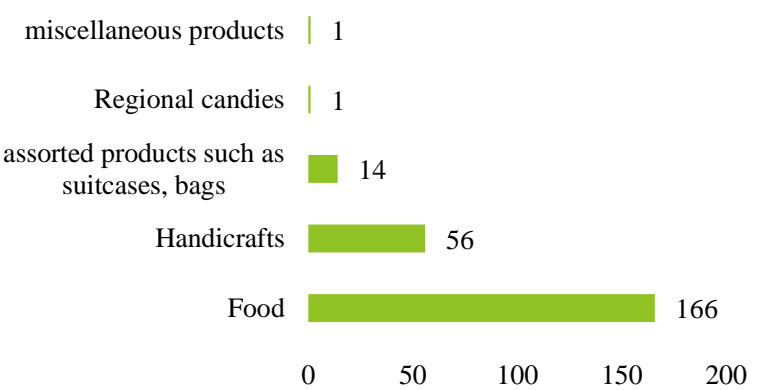

Graphic 6 Products that can be offered to tourists

$83.8 \%$ of those surveyed can offer food services, while $28.3 \%$ could offer handicraft products and the remaining $7.1 \%$ responded that they could offer various products such as bags, suitcases and regional sweets.

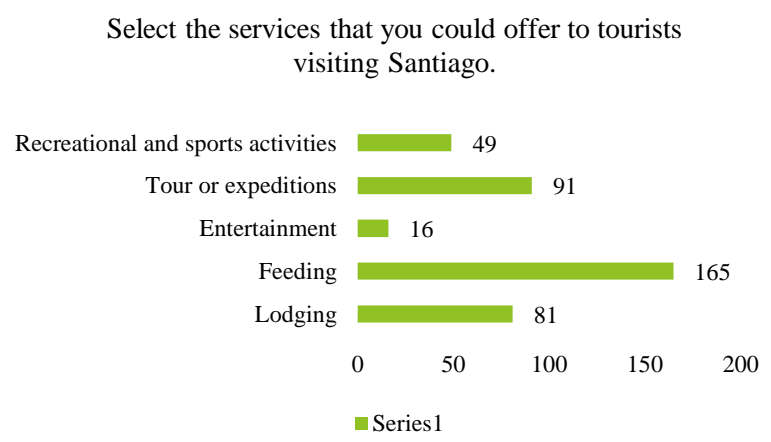

Graphic 7 Services that can be provided to tourists
ROBLES-ARIAS, Isela Margarita, FLORES-MEZA, Jhony Ramon, SANDOVAL-GARCIA, Brian and VALDEZ-GUERRERO, Raquel. Alternative tourism through product and service networks for the development of Santiago, of the Cabo del Este Region of the Municipality of Los Cabos. RINOE Journal- General Economics. 2020 
$83.3 \%$ of the total respondents could offer food services, while $46 \%$ responded that they could offer tours and expeditions, $40.9 \%$ of the total responded that they could offer lodging services, $24.7 \%$ could offer recreational activities and $8.1 \%$ could offer entertainment services

3. Survey of residents of La Paz to determine the interest of the inhabitants of the city of La Paz about tourist attractions and products of Santiago. It was designed in Google forms, it was applied through social networks asking to answer and share with the contacts. How to obtain the sample.

The residents of the city of La Paz are a total of 301,961 according to data from the (National Institute of Statistics and Geography, 2020), simple random sampling was used with a margin of error of $9 \%$ and a confidence level of $98 \%$ for a sample of 167 .

Would you be interested in visiting the community of Santiago?

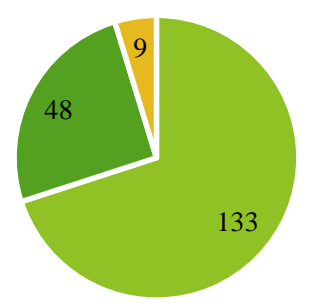

- Yes - Do not - I do not know the community of Santiago.

Graphic 8 Interest of the inhabitants of La Paz to visit the community of Santiago

The previous graph showed us that $70 \%$ of those surveyed are interested in knowing the community of Santiago, while $25.3 \%$ do not know the community of Santiago and $4.7 \%$ are not interested in visiting said community.

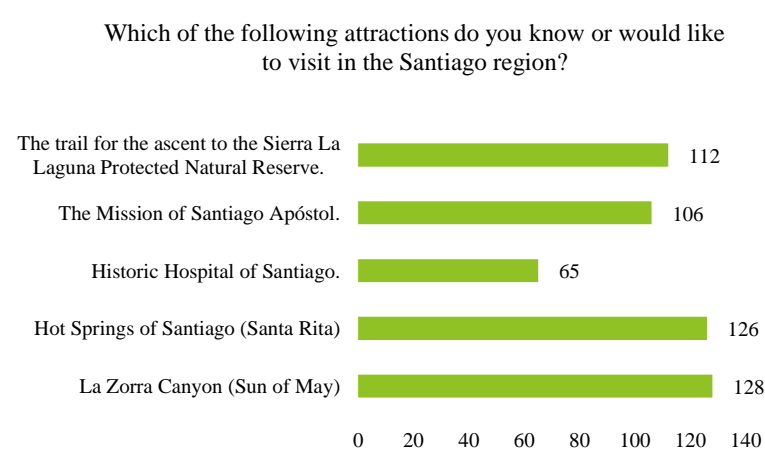

Graphic 9 Knowledge or interest in knowing attractions of the Santiago region
The graph shown above shows that of the total of those surveyed, $67.4 \%$ know or would like to know the fox canyon, $66.3 \%$ the hot springs, $58.9 \%$ the path to the ascent to the Sierra de the lagoon, $55.8 \%$ the mission of Santiago apóstol, and 34.2\% the historic hospital.

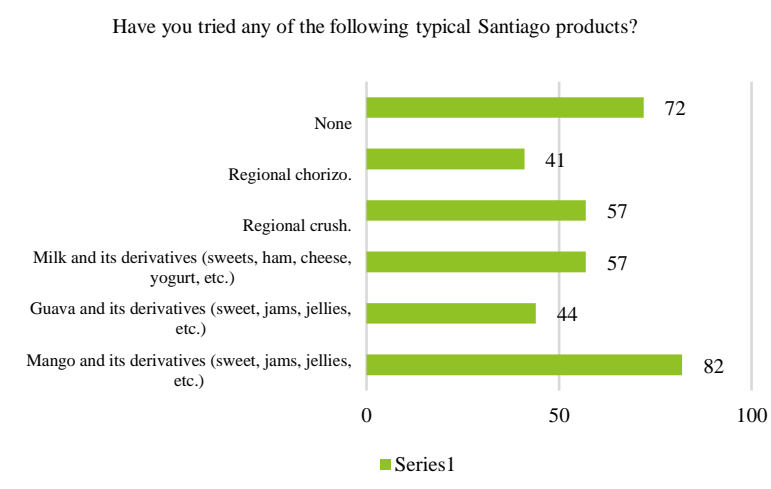

Graphic 10 knowledge of Santiago products

The graph shown above shows us that of the total of those surveyed, $43.2 \%$ have tried mango or its derivatives, while $30 \%$ have tried milk and its derivatives and another $30 \%$ have tried machaca, 23.2 responded that they have tried guava sweets and its derivatives, 21.6 have tried regional chorizo and $30 \%$ of those surveyed have not tried any of the typical products mentioned above.

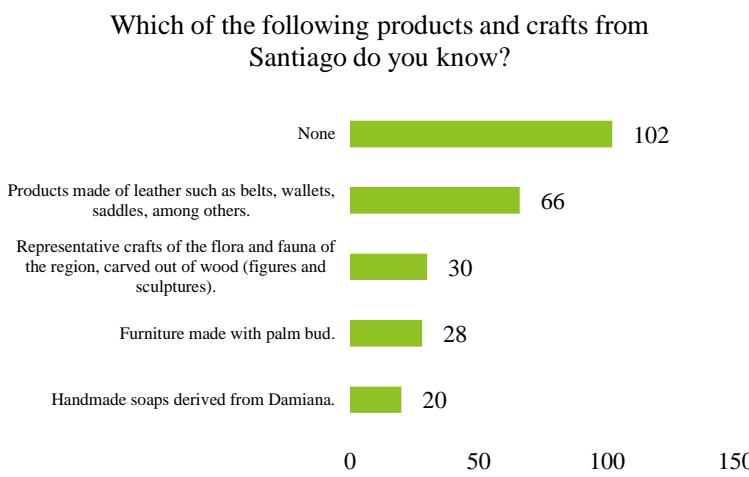

Graphic 11 knowledge of products and crafts native to Santiago

The graph shown above showed us that of the total of those surveyed, $53.7 \%$ do not know any of the products or crafts from the Santiago community, $34.7 \%$ responded that they know products made from leather, 15,8 who know representative crafts of the community, $14.7 \%$ know products made with palm hearts and $10.5 \%$ answered that they knew handmade soaps derived from Damiana. 


\section{Analysis of the information}

Based on the results obtained through the first survey, it can be interpreted that there is interest on the part of the inhabitants of the community of Santiago to start or position their businesses in such a way that they are oriented to an economic development of the region for the well-being and progress of themselves and their families.

This is possible through the tourism development of the region through the creation of a network of products and services, however, an external intervention is necessary given that they lack information and require advice to be able to consolidate the network model of tourism products and services, however, the intervention should be mainly focused on the prosperity of the natives and not third parties as has happened in other regions of the peninsula.

Thanks to the information that the second survey gave us, it showed the interest of this to visit the community due to the tourist attractions of the area and the wealth of its products.

\section{SWOT analysis}

Based on the information obtained through the applied instruments, the following diagnosis was made using the administrative tool called SWOT Analysis.

\begin{tabular}{|c|c|}
\hline Strength & Opportunity \\
\hline $\begin{array}{l}\text { 1. Close to the } \\
\text { municipality of Los } \\
\text { Cabos. } \\
\text { 2. Abundant natural } \\
\text { tourist attractions. } \\
\text { 3. The community has } \\
\text { been declared a historic } \\
\text { site. } \\
\text { 4. Diversity of regional } \\
\text { seasonal products. } \\
5 \text { Willingness of the } \\
\text { inhabitants of Santiago } \\
\text { to undertake business } \\
\text { for tourism purposes. } \\
6 \text { It has personnel with } \\
\text { skills to make artisan } \\
\text { products. } \\
7 \text { It has attractive } \\
\text { events and / or parties } \\
\text { for tourism. } \\
\text { 8. Adequate climate for } \\
\text { tourism development } \\
\text { and production of } \\
\text { various endemic fruits } \\
\text { of Santiago. }\end{array}$ & $\begin{array}{l}\text { 1. Positioning of the State as } \\
\text { a tourist agent. } \\
\text { 2. Expand Internet coverage } \\
\text { as a means of promoting the } \\
\text { tourist offer. } \\
\text { 3. Growth of the tourist } \\
\text { market in the southern part } \\
\text { of the State. } \\
\text { 4. Existence of educational } \\
\text { programs for young people } \\
\text { of upper and upper } \\
\text { secondary level focused on } \\
\text { tourism (CECYT and ITES). } \\
5 \text {. Willingness of the local } \\
\text { tourist to visit the } \\
\text { community. } \\
6 \text {. Development of tourist } \\
\text { services focused on } \\
\text { alternative tourism. } \\
7 \text { Design a logo that } \\
\text { represents the products } \\
\text { made in the región }\end{array}$ \\
\hline
\end{tabular}

\begin{tabular}{|c|c|}
\hline $\begin{array}{l}\text { 9. There is a variety of } \\
\text { representative crafts } \\
\text { from Baja California } \\
\text { Sur. } \\
10 \text {. The artisan products } \\
\text { that are marketed are of } \\
\text { good quality. } \\
11 \text {. The products are } \\
\text { made by local artisans, } \\
\text { and each craft is unique. }\end{array}$ & \\
\hline Weakness & Threat \\
\hline $\begin{array}{l}\text { 1. Lack of } \\
\text { infrastructure for } \\
\text { accommodation and } \\
\text { food. } \\
\text { 2. Lack of tourist signs. } \\
\text { 3. Sometimes the } \\
\text { sections of the roads } \\
\text { leading to the town are } \\
\text { affected by the rains. } \\
\text { 4. Ignorance of the } \\
\text { inhabitants to lower } \\
\text { financial resources. } \\
5 \text {. Poor quality of } \\
\text { services offered } \\
6 . \text { Little organization } \\
\text { and communication in } \\
\text { the community. } \\
7 \text { Little knowledge of } \\
\text { speaking the foreign } \\
\text { language. } \\
\text { 8. Lack of knowledge } \\
\text { of the use of computer } \\
\text { tools (computer, } \\
\text { Smartphone) } \\
\text { 9. Lack of training to } \\
\text { provide quality service } \\
\text { 10. Poor tourism } \\
\text { promotion. } \\
\text { 11. Lack of economic } \\
\text { activation in the region. } \\
\text { 12. Uncontrol of prices } \\
\text { in services. } \\
\text { 13. There is little } \\
\text { network coverage for } \\
\text { mobile telephony. } \\
\text { 14. No card payments } \\
\text { or bank transfers }\end{array}$ & $\begin{array}{l}\text { 1. Little tourist visit during } \\
\text { some seasons } \\
\text { 2. Tourism development of } \\
\text { other areas and communities } \\
\text { in the State. } \\
\text { 3. Migration of inhabitants } \\
\text { of Santiago due to lack of } \\
\text { opportunities. } \\
\text { 4. By not having the } \\
\text { establishment's } \\
\text { dissemination on social } \\
\text { networks or the internet, } \\
\text { some people do not know } \\
\text { about this option to buy local } \\
\text { crafts }\end{array}$ \\
\hline
\end{tabular}

Table 1 SWOT analysis

\section{Cause-effect diagram}

With the cause and effect diagram it is sought to outline and represent in 4 large sectors that are integrated by Government, Inhabitants, Resources and Marketing, which lead to different problems or circumstances that jointly result in a lack for the economic development of Santiago. 


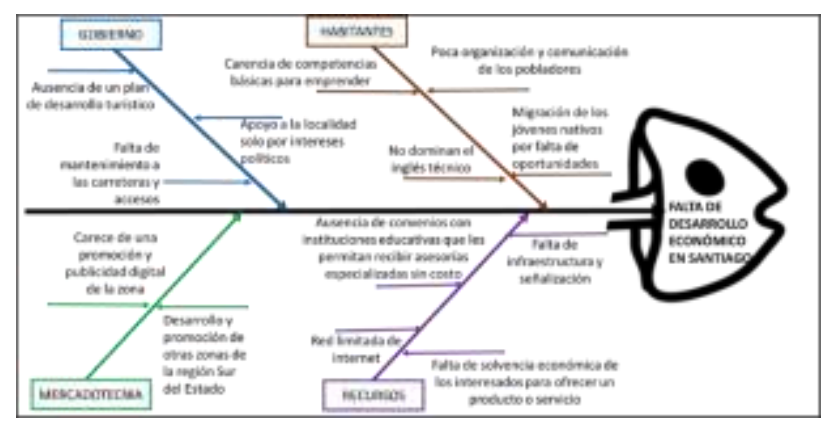

Figure 2 Cause-effect diagram

\section{CFKE analysis}

El análisis CFKE que se muestra a continuación tiene como objetivo el plantear un cierto número de estrategias posibles para complementar el análisis FODA y, por consiguiente, dar solución a la problemática mediante un plan estratégico.

\begin{tabular}{|c|c|}
\hline Correct & Front facing \\
\hline $\begin{array}{l}\text { Strategy } 1 . \\
\text { Prepare signage for tourist } \\
\text { places. } \\
\text { Strategy } 2 \text {. } \\
\text { Advise the interested party to } \\
\text { manage it with federal } \\
\text { support (support for women, } \\
\text { non-refundable funds, for } \\
\text { SMEs, etc. } \\
\text { Strategy } 3 \text {. } \\
\text { Positioning of the region as a } \\
\text { tourist product, unifying the } \\
\text { providers of services and } \\
\text { products } \\
\text { representative logo of the } \\
\text { region. } \\
\text { Strategy } 4 \text {. } \\
\text { Teaching technical English } \\
\text { and computer courses } \\
\text { through agreements with } \\
\text { universities. } \\
\text { Strategy } 5 \text {. } \\
\text { Integration of a committee } \\
\text { for the establishment of a } \\
\text { network of products and } \\
\text { services with residents of } \\
\text { Santiago and specialized } \\
\text { advisers. }\end{array}$ & $\begin{array}{l}\text { Strategy } 1 . \\
\text { Carry out national and } \\
\text { international promotion. } \\
\text { (Videos, brochures, website, } \\
\text { social networks). } \\
\text { Strategy } 2 . \\
\text { Determine a standardized } \\
\text { price tabulation for healthy } \\
\text { competition. } \\
\text { Strategy } 3 \text {. } \\
\text { Make agreements with } \\
\text { educational institutions with } \\
\text { careers related to tourism to } \\
\text { carry out their practices } \\
\text { within the region } \\
\text { Strategy } 4 . \\
\text { Appoint an ejido chief to } \\
\text { integrate an association of } \\
\text { producers and farmers for } \\
\text { decision-making. } \\
\text { Strategy } 5 \text {. } \\
\text { Coordination with SETUES } \\
\text { for the design of a } \\
\text { comprehensive development } \\
\text { plan for the region, using } \\
\text { financial resources to } \\
\text { encourage economic } \\
\text { activation. }\end{array}$ \\
\hline Keep & Exploit \\
\hline 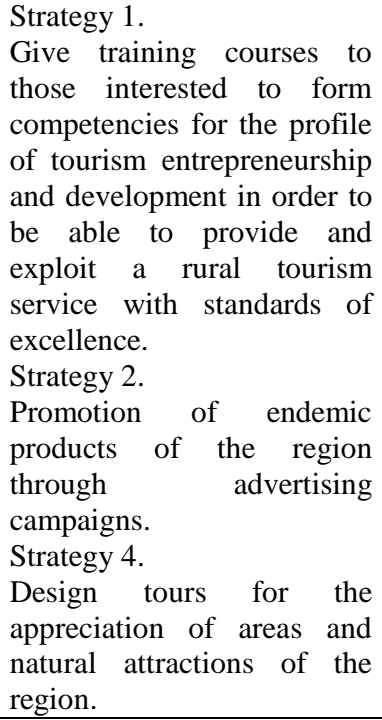 & $\begin{array}{l}\text { Strategy } 1 . \\
\text { Make strategic alliances with } \\
\text { travel agencies, hotels and } \\
\text { tourism service providers. } \\
\text { Strategy } 2 \text {. } \\
\text { Increase the capture of local } \\
\text { and state tourism. } \\
\text { Strategy } 3 \text {. } \\
\text { Provide training to the } \\
\text { inhabitants about the new } \\
\text { tourist trends and how to } \\
\text { implement them in their } \\
\text { community. } \\
\text { Strategy } 4 . \\
\text { Coordination with the } \\
\text { Ministry of Public Education } \\
\text { to obtain scholarships for } \\
\text { undergraduate and graduate } \\
\text { level projects for the }\end{array}$ \\
\hline
\end{tabular}

\begin{tabular}{|l|l|}
\hline $\begin{array}{l}\text { Strategy 5. } \\
\text { Improve the coordination } \\
\text { and communication of the } \\
\text { inhabitants to offer a unique } \\
\text { service as a community. }\end{array}$ & $\begin{array}{l}\text { development of the Santiago } \\
\text { Community. } \\
\text { Coordination of the } \\
\text { inhabitants to request an } \\
\text { improvement of road and } \\
\text { telecommunications } \\
\text { infrastructure } \\
\text { Strategy 6. } \\
\text { Implement payment with } \\
\text { credit and debit cards } \\
\text { through the internet }\end{array}$ \\
\hline
\end{tabular}

Table 3 CFKE analysis

\section{Results obtained}

\section{Introduction}

The planning and design of alternative services present a series of problems that, if not addressed by means of an appropriate methodology, will be difficult to solve due to the intricacy and extensive information required, as well as the multiple agents involved in this process, which must be first of all concerted, without forgetting, of course, that all this has to take place within the parameters of sustainability that make it possible.

A close relationship between the tourist and the environment that surrounds them, both natural and human, is essential to live a personal, unique, unrepeatable experience in a quality environment so that it becomes a tourist. This consideration suggests a reflection on how to plan and design these same experiences and experiences. It requires its own methodology, which, although it is based on the experiences of conventional tourism, has another approach, in addition to providing new points of view, technical, social, environmental, psychological considerations, etc., which allow the creation of models and sustainable tourism services.

\section{Description of the town}

The community of Santiago is located approximately 135 kilometers south of the state capital and approximately 45 kilometers from San José del Cabo. It has an approximate population of 783 inhabitants according to the data provided by the National Institute of Statistics and Geography. It is a small community that is mainly dedicated to rural and artisan activities, such as food production or the elaboration of various artisan products. 
This town has a warm climate given the geographical and environmental conditions of the region, however, it is an area that is characterized by being within the Tropic of Cancer. These climatic and environmental conditions allow the abundance of different species of flora and fauna throughout the region.

The majority of the population living in the region are adults and older adults, given the conditions due to the lack of opportunities for professional development, which results in young people tending to emigrate to other cities, being one of the factors for which has not been able to generate a planned and structured development of the community that avoids this phenomenon.

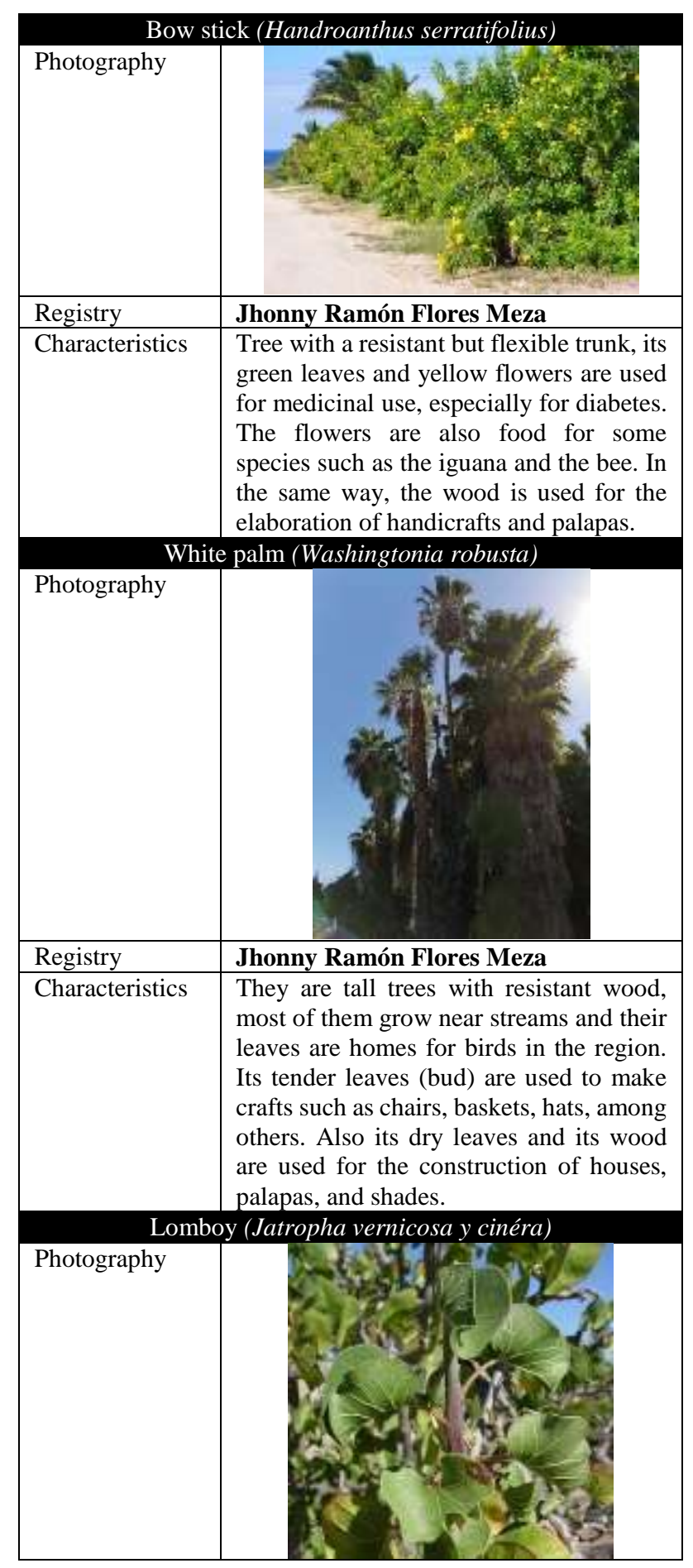

ISSN-On line: 2524-2008

RINOE $^{\circledR}$ All rights reserved.

\begin{tabular}{|c|c|}
\hline Registry & Jhonny Ramón Flores Meza \\
\hline Characteristics & $\begin{array}{l}\text { Plant with great antiseptic and hemostatic } \\
\text { medicinal properties (coagulants) which } \\
\text { serves to heal wounds on the skin. During } \\
\text { the rainy season its leaves are intense } \\
\text { green but in autumn seasons its leaf is } \\
\text { deciduous, so we can find them without } \\
\text { leaves and with fruits that serve as food } \\
\text { for birds of the region such as the white- } \\
\text { winged dove. }\end{array}$ \\
\hline \multicolumn{2}{|r|}{ Quiote (Agave aurea) } \\
\hline \multicolumn{2}{|l|}{ Photography } \\
\hline Registry & \multirow[b]{2}{*}{$\begin{array}{l}\text { Jhonny Ramón Flores Meza } \\
\text { Plant that occurs in the softwood region, } \\
\text { its cane is used for medicinal use, } \\
\text { especially for cleaning urinary tract. In } \\
\text { rainy seasons its flower serves as food for } \\
\text { animals and people. After the tree is dead, } \\
\text { many people use it as an ornament during } \\
\text { the Christmas season. }\end{array}$} \\
\hline Characteristics & \\
\hline \multicolumn{2}{|r|}{ Damiana (Turnera difussa) } \\
\hline \multicolumn{2}{|l|}{ Photography } \\
\hline Registry & Jhonny Ramón Flores Meza \\
\hline Characteristics & $\begin{array}{l}\text { Medicinal plant. It is effective for treating } \\
\text { depression, cough, fatigue and stimulates } \\
\text { the central nervous system. It can be } \\
\text { served as tea or water for use, in the same } \\
\text { way soaps and liquor can be made. The } \\
\text { best time to cut the plant is after the rains } \\
\text { when it sprouts and blooms, and it also } \\
\text { emits a pleasant smell that is easy to } \\
\text { detect. }\end{array}$ \\
\hline \multicolumn{2}{|c|}{ White stick (Lysiloma divaricatum) } \\
\hline \multicolumn{2}{|c|}{\begin{tabular}{l|l|l|l|l|l|l|l|l} 
Photography &
\end{tabular}} \\
\hline Registry & Jhonny Ramón Flores Meza \\
\hline Characteristics & $\begin{array}{l}\text { Endemic tree of Baja California Sur, its } \\
\text { white bark can be used for leather work } \\
\text { (tanning animal skin), they grow from } 3 \\
\text { to } 10 \text { meters in height. In the rainy season } \\
\text { and in spring, the tree blooms as food for } \\
\text { bees and its fruit is in the form of a green } \\
\text { bean used to feed cattle. When the tree } \\
\text { dries up, its wood can be used to make } \\
\text { furniture, poles or for firewood in the } \\
\text { ranches. }\end{array}$ \\
\hline
\end{tabular}

ROBLES-ARIAS, Isela Margarita, FLORES-MEZA, Jhony Ramon, SANDOVAL-GARCIA, Brian and VALDEZ-GUERRERO, Raquel. Alternative tourism through product and service networks for the development of Santiago, of the Cabo del Este Region of the Municipality of Los Cabos. RINOE Journal- General Economics. 2020 


\begin{tabular}{|c|c|}
\hline \multicolumn{2}{|r|}{ Mesquite (prosopis glandulosa) } \\
\hline Photography & \\
\hline Registry & \multirow[b]{2}{*}{$\begin{array}{l}\text { Jhonny Ramón Flores Meza } \\
\text { Tree that can reach } 9 \text { meters in height, the } \\
\text { fruit that these bear are pod-shaped. Its } \\
\text { flower is nectar for bees. They are trees that } \\
\text { usually provide good shade for animals and } \\
\text { their wood is very hard, which is used for } \\
\text { making furniture or firewood. }\end{array}$} \\
\hline Characteristics & \\
\hline \multicolumn{2}{|r|}{ Cat's claw (Mimosa distachya) } \\
\hline \multicolumn{2}{|l|}{ Photography } \\
\hline Registry & Jhonny Ramón Flores Meza \\
\hline Characteristics & $\begin{array}{l}\text { Common wild tree, its seed is used to treat } \\
\text { epilepsy. In the spring season its flower is } \\
\text { used as food for bees and small insects. }\end{array}$ \\
\hline \multicolumn{2}{|c|}{ Mount plum (Cyrtocarpa edulis) } \\
\hline \multicolumn{2}{|c|}{ Photography } \\
\hline Registry & Jhonny Ramón Flores Meza \\
\hline Characteristics & $\begin{array}{l}\text { It is a wild tree, with mostly thick stems that } \\
\text { reach heights of up to } 10 \text { meters of grayish } \\
\text { color. Its fruit (plum) can be found in } \\
\text { summer and autumn which serves as food } \\
\text { for the animals of the region. }\end{array}$ \\
\hline \multicolumn{2}{|r|}{ Torote (Bursera microphylla) } \\
\hline \multicolumn{2}{|l|}{ Photography } \\
\hline Registry & Jhonny Ramón Flores Meza \\
\hline Characteristics & $\begin{array}{l}\text { Tree with a yellow trunk, it produces small } \\
\text { flowers and fruits, most of which are } \\
\text { consumed by birds such as the white- } \\
\text { winged dove that lives in the region. Most } \\
\text { of the year it is found in leaves, but with the } \\
\text { arrival of summer it begins to produce them. }\end{array}$ \\
\hline
\end{tabular}
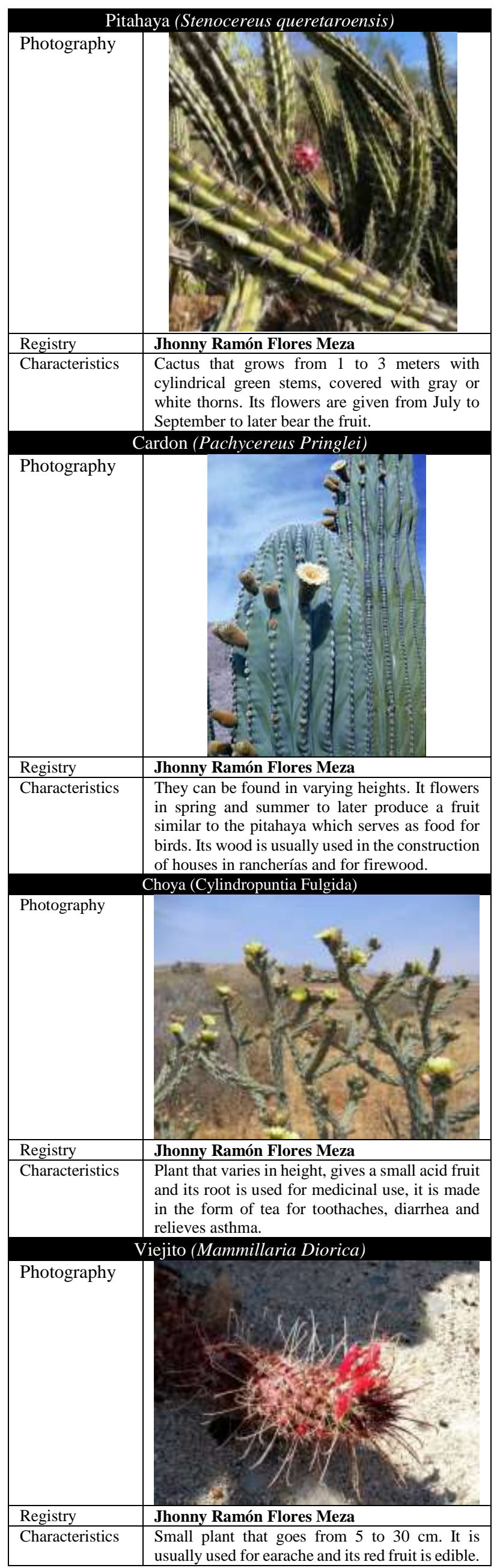

Table 4 Flora Inventory

ROBLES-ARIAS, Isela Margarita, FLORES-MEZA, Jhony Ramon, SANDOVAL-GARCIA, Brian and VALDEZ-GUERRERO, Raquel. Alternative tourism through product and service networks for the development of Santiago, of the Cabo del Este Region of the Municipality of Los Cabos. RINOE Journal- General Economics. 2020 


\begin{tabular}{|c|c|}
\hline \multicolumn{2}{|c|}{ Rattlesnake (Crotalus durissus) } \\
\hline \multicolumn{2}{|l|}{ Photography } \\
\hline Registry & Jhonny Ramón Flores Meza \\
\hline Characteristics & $\begin{array}{l}\text { It is a poisonous species, it can reach up } \\
\text { to two meters in length, its skin is scaly, } \\
\text { its spine is very prominent. Their } \\
\text { hibernation season begins in November in } \\
\text { which they get into their burrows and we } \\
\text { can see them again in February. }\end{array}$ \\
\hline \multicolumn{2}{|r|}{ Hare (Lepus Californicus) } \\
\hline \multicolumn{2}{|l|}{ Photography } \\
\hline Registry & Jhonny Ramón Flores Meza \\
\hline Characteristics & $\begin{array}{l}\text { It is a species of grayish mammal with } \\
\text { white spots and the tips of the ears and the } \\
\text { tail is black, its body can reach } 50 \mathrm{~cm} \text { in } \\
\text { height and it can weigh up to } 2.5 \mathrm{~kg} \text {. }\end{array}$ \\
\hline \multicolumn{2}{|c|}{ Mount cat (Lynx rufux peninsularis) } \\
\hline \multicolumn{2}{|c|}{ 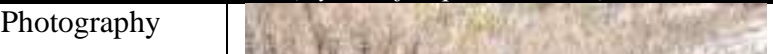 } \\
\hline Registry & Jhonny Ramón Flores Meza \\
\hline Characteristics & $\begin{array}{l}\text { It is a species that is adapted to living in } \\
\text { desert areas and scrub areas. It is a } \\
\text { medium-sized feline and can reach up to } \\
20 \mathrm{~kg} \text {, is reddish-brown in color and } \\
\text { usually feeds on hares, rodents and } \\
\text { chickens. }\end{array}$ \\
\hline \multicolumn{2}{|c|}{ Roadrunner (Geococcyx Californianus) } \\
\hline Photography & \\
\hline Registry & Jhonny Ramón Flores Meza \\
\hline Characteristics & $\begin{array}{l}\text { It is a grayish-black bird, has great agility } \\
\text { in its legs and can reach } 30 \mathrm{~km} / \mathrm{h} \text {. This } \\
\text { species reaches up to } 52 \mathrm{~cm} \text { in height. It is } \\
\text { also known by the local inhabitants as } \\
\text { "churea". It nests in bushes and cardones } \\
\text { and usually feeds on small insects and } \\
\text { reptiles such as snakes. }\end{array}$ \\
\hline
\end{tabular}
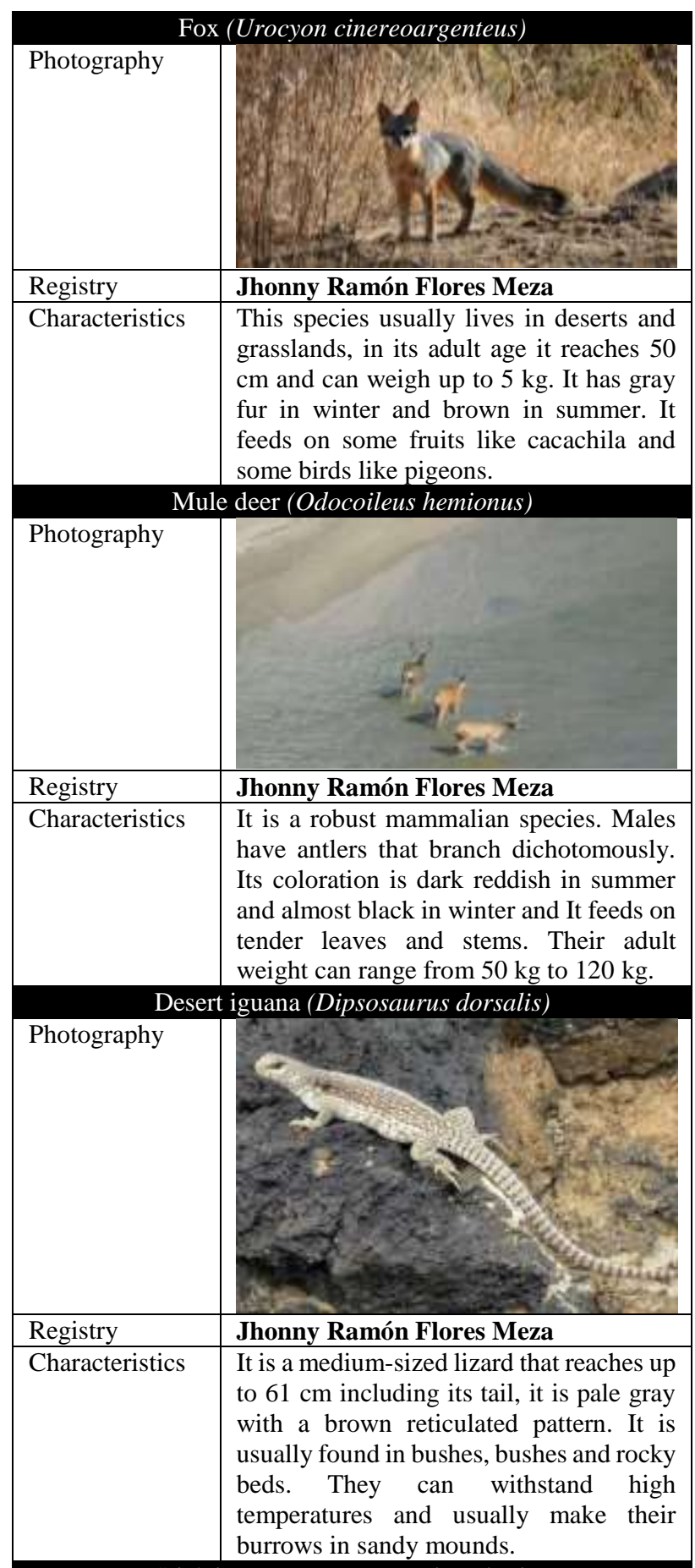

\begin{tabular}{|l|l|}
\hline \multicolumn{2}{|c|}{ Stick iguana (Ctenosaura hemilopha) } \\
\hline Photography
\end{tabular}




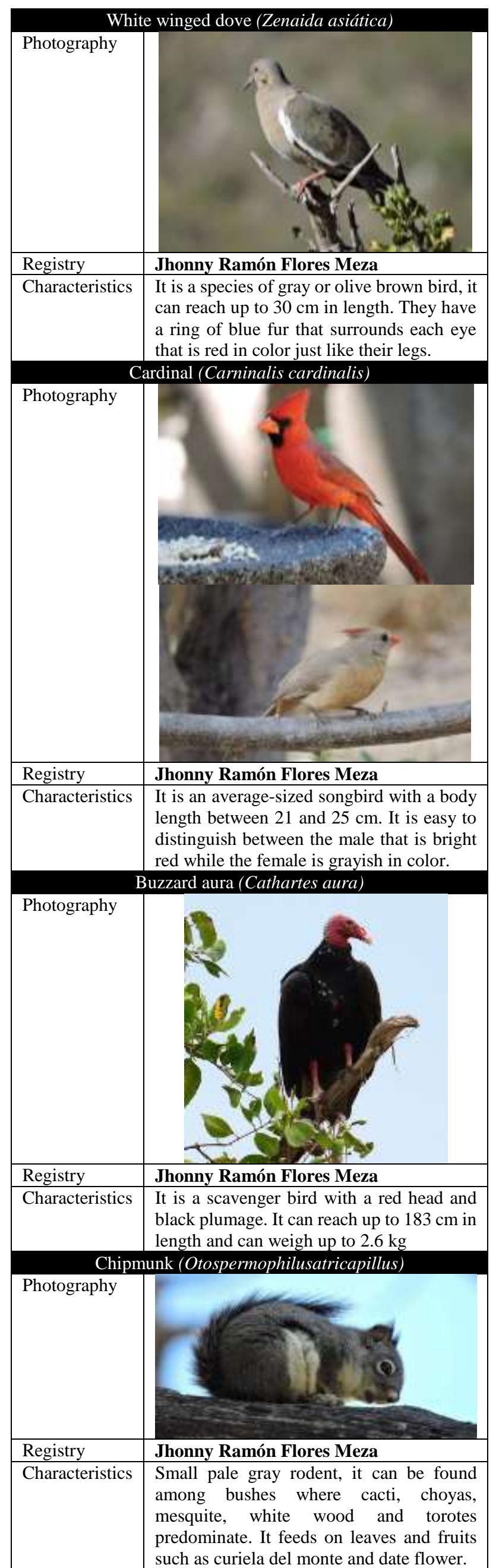

Table 5 Fauna Inventory

ISSN-On line: 2524-2008

RINOE $^{\circledR}$ All rights reserved.

\begin{tabular}{|c|c|c|}
\hline $\begin{array}{l}\text { Name of the } \\
\text { attraction }\end{array}$ & Category & Type \\
\hline $\begin{array}{l}\text { Fox cannon } \\
\text { Or sun of May }\end{array}$ & Natural site & Waterfall (waterfall) \\
\hline \multicolumn{3}{|l|}{ Picture } \\
\hline Location & \multicolumn{2}{|c|}{$\begin{array}{l}\text { Located on the outskirts of the community } \\
\text { of Santiago is } 10 \mathrm{~km} \text {. }\end{array}$} \\
\hline Characteristic & \multicolumn{2}{|c|}{$\begin{array}{l}\text { It has a dirt road. To get to the waterfall you } \\
\text { have to walk } 300 \text { meters. Where we can find } \\
\text { a stream of calm water of crystalline green } \\
\text { color. } \\
\text { In this area we can find a large amount of } \\
\text { flora and fauna landscape in which you can } \\
\text { take photographs and interpretive hiking. }\end{array}$} \\
\hline Santa Rita & Natural site & Thermal waters \\
\hline \multicolumn{3}{|l|}{ Picture } \\
\hline Location & \multicolumn{2}{|c|}{$\begin{array}{l}\text { It is located } 9.3 \mathrm{~km} \text { from Santiago on a dirt } \\
\text { road. }\end{array}$} \\
\hline Characteristic & \multicolumn{2}{|c|}{$\begin{array}{l}\text { Its waters are mineralized that are found in } \\
\text { the running of a stream, have healing } \\
\text { properties and reach } 55^{\circ} \mathrm{C} \text {. Same that gives } \\
\text { a feeling of relaxation to the body. It is } \\
\text { surrounded by very rich and diverse flora } \\
\text { and fauna for Photography and hiking. }\end{array}$} \\
\hline Dark pool & Natural site & pool \\
\hline \multicolumn{3}{|l|}{ Picture } \\
\hline Location & \multicolumn{2}{|c|}{$\begin{array}{l}\text { It is located } 9 \mathrm{~km} \text { from Santiago and is } \\
\text { entered by car on a dirt road. }\end{array}$} \\
\hline Characteristic & \multicolumn{2}{|c|}{$\begin{array}{l}\text { To descend to the pool it is necessary to } \\
\text { walk downhill } 500 \text { meters. It claims to be } \\
\text { one of the deepest pools in the region, its } \\
\text { depth reaches } 15 \text { meters and it is } \\
\text { surrounded by a stone cliff. It can be } \\
\text { crossed by swimming from shore to shore } \\
\text { which is } 6 \text { meters long. }\end{array}$} \\
\hline $\begin{array}{l}\text { San Dionisio } \\
\text { canyon }\end{array}$ & Natural site & Stream \\
\hline
\end{tabular}

ROBLES-ARIAS, Isela Margarita, FLORES-MEZA, Jhony Ramon, SANDOVAL-GARCIA, Brian and VALDEZ-GUERRERO, Raquel. Alternative tourism through product and service networks for the development of Santiago, of the Cabo del Este Region of the Municipality of Los Cabos. RINOE Journal- General Economics. 2020 


\begin{tabular}{|c|c|}
\hline Picture & \\
\hline Location & $\begin{array}{l}\text { Located } 9 \mathrm{~km} \text { from the community of } \\
\text { Santiago with a maximum of } 20 \text {. }\end{array}$ \\
\hline Characteristic & $\begin{array}{l}\text { You can travel by car the } 20 \mathrm{~km} \text { on a dirt } \\
\text { road, it has a stream that is born in the } \\
\text { biosphere reserve "Sierra de la laguna" } \\
\text { maintaining its flow throughout the year, } \\
\text { the best months to visit are after the rains } \\
\text { when there is greater flow of water and its } \\
\text { colorful landscapes. }\end{array}$ \\
\hline The shelter & \begin{tabular}{l|l} 
Natural site & Interpretive hiking hike
\end{tabular} \\
\hline Picture & lita, Avenitura y Lideraxło I \\
\hline Location & $\begin{array}{l}\text { Located } 14 \mathrm{~km} \text { from the community of } \\
\text { Santiago. }\end{array}$ \\
\hline Characteristic & $\begin{array}{l}\text { The } 14 \mathrm{~km} \text { dirt road can be reached by car. } \\
\text { It is a ranch where they offer walks to } \\
\text { different points. They teach you the flora } \\
\text { and fauna corresponding to the place. }\end{array}$ \\
\hline $\begin{array}{l}\text { Baja sierra } \\
\text { adventure }\end{array}$ & \begin{tabular}{l|l} 
Natural site & cycling \\
\end{tabular} \\
\hline Picture & \\
\hline Location & Located within the town of Santiago \\
\hline Characteristic & $\begin{array}{l}\text { Small eco-tourism company that provides } \\
\text { cycling services, starting from the outskirts } \\
\text { of the community and ending in the center } \\
\text { of the town of Santiago, especially for } \\
\text { people who like this Type of } \\
\text { entertainment. At the same time, you can } \\
\text { observe the wealth that the places where } \\
\text { the activity takes place have. }\end{array}$ \\
\hline
\end{tabular}

Table 6 Inventory of Tourist Attractions

\begin{tabular}{|c|c|}
\hline $\begin{array}{l}\text { Name of the } \\
\text { attraction }\end{array}$ & Category \\
\hline $\begin{array}{l}\text { Santiago } \\
\text { Apostle } \\
\text { Church }\end{array}$ & Architecture \\
\hline \multicolumn{2}{|l|}{ Picture } \\
\hline Location & $\begin{array}{l}\text { Santiago. } 250 \text { meters from the main } \\
\text { entrance }\end{array}$ \\
\hline Characteristic & $\begin{array}{l}\text { Church located within the mission } \\
\text { routes, was built in } 1721 \text { and since then } \\
\text { several modifications and maintenance } \\
\text { have been carried out. It is one of the } \\
\text { historical and representative places of } \\
\text { the community. }\end{array}$ \\
\hline $\begin{array}{l}\begin{array}{l}\text { Ecological } \\
\text { cabins sol de } \\
\text { mayo }\end{array} \\
\end{array}$ & \begin{tabular}{l|l} 
Architecture & cabin
\end{tabular} \\
\hline \multicolumn{2}{|l|}{ Picture } \\
\hline Location & $\begin{array}{l}\text { It is located } 10 \mathrm{~km} \text { from the community } \\
\text { of Santiago }\end{array}$ \\
\hline Characteristic & $\begin{array}{l}\text { Simple cabins for camping, it has the } \\
\text { necessary accessories to spend a } \\
\text { pleasant stay near attractive natural } \\
\text { sites. }\end{array}$ \\
\hline $\begin{array}{l}\text { Hospital el } \\
\text { carrizalito }\end{array}$ & \begin{tabular}{l|l} 
Architecture & Hospital
\end{tabular} \\
\hline \multicolumn{2}{|l|}{ Picture } \\
\hline Location & $\begin{array}{l}\text { It is located } 22 \mathrm{~km} \text { from the community } \\
\text { of Santiago, and } 13 \mathrm{~km} \text { from the federal } \\
\text { highway entering through the } \\
\text { community of the camp. }\end{array}$ \\
\hline Characteristic & $\begin{array}{l}\text { Remains of an abandoned hospital, it } \\
\text { was built for people with tuberculosis } \\
\text { for the years 1940-1960. }\end{array}$ \\
\hline
\end{tabular}

Table 7 Architectural inventory 


\begin{tabular}{|c|c|}
\hline & Beef Machaca \\
\hline Description & $\begin{array}{l}\text { Typical food of the region, which can be } \\
\text { found in certain establishments in the } \\
\text { community, its preparation varies with } \\
\text { some ingredients but the most common } \\
\text { are green chili, potato and onion. It can } \\
\text { be accompanied with beans, cheese and a } \\
\text { cup of coffee. }\end{array}$ \\
\hline Picture & \\
\hline & Mango sweet \\
\hline Description & $\begin{array}{l}\text { Sweet made from mango pulp while the } \\
\text { fruit is ready. It is usually found in } \\
\text { stores, expos and restaurants. The sweet } \\
\text { can be kept refrigerated for up to } 12 \\
\text { months after it is made. The production } \\
\text { months are from June to August. }\end{array}$ \\
\hline Picture & \\
\hline & Guava sweet \\
\hline Description & $\begin{array}{l}\text { Sweet made from the pulp of the fruit } \\
\text { with sweetener (sugar) for better } \\
\text { conservation. We can find it in } \\
\text { community stores, exhibitions and by } \\
\text { ordering directly with the supplier. }\end{array}$ \\
\hline Picture & \\
\hline & Ham \\
\hline Description & $\begin{array}{l}\text { Regional sweet made from whole milk } \\
\text { with sweetener (sugar) that can be found } \\
\text { in different presentations. (bars, circular } \\
\text { among others.) }\end{array}$ \\
\hline
\end{tabular}

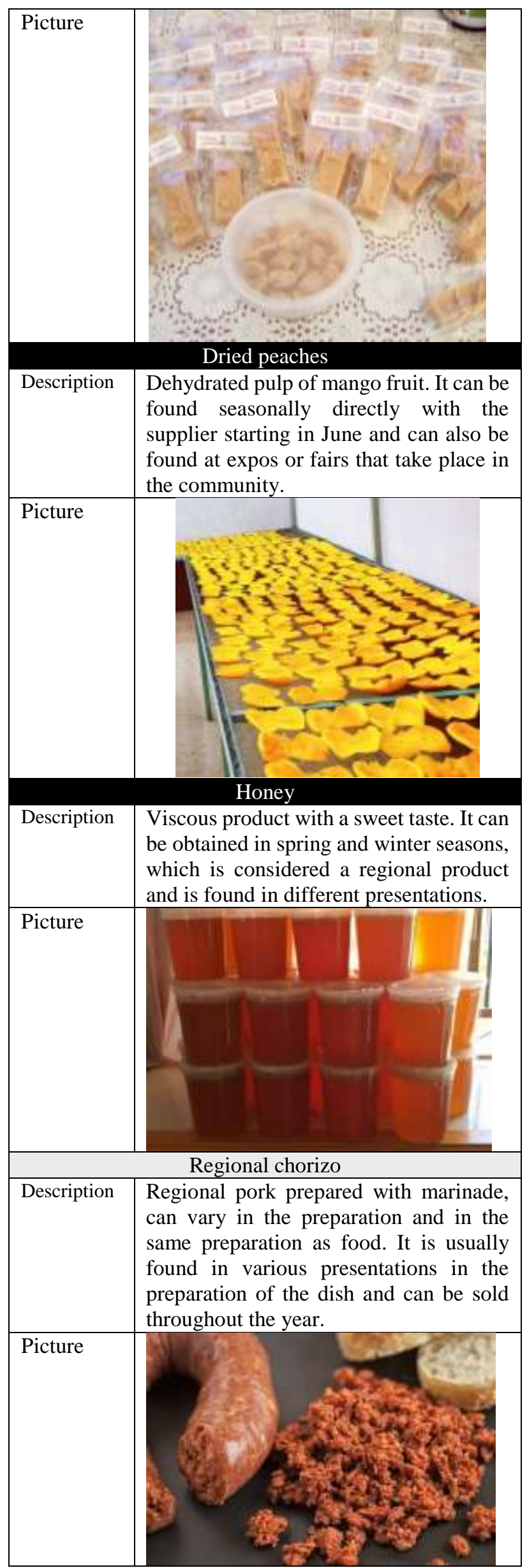

ROBLES-ARIAS, Isela Margarita, FLORES-MEZA, Jhony Ramon, SANDOVAL-GARCIA, Brian and VALDEZ-GUERRERO, Raquel. Alternative tourism through product and service networks for the development of Santiago, of the Cabo del Este Region of the Municipality of Los Cabos. RINOE Journal- General Economics. 2020 


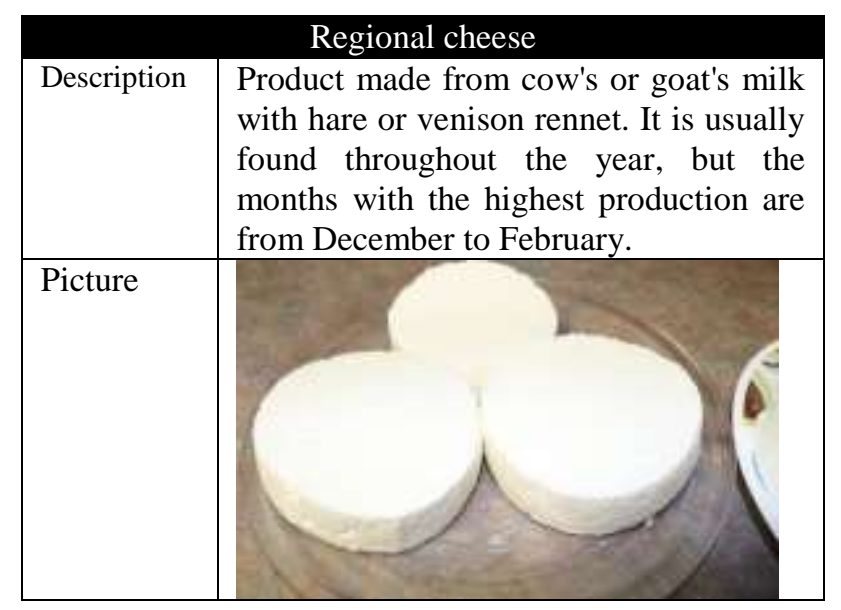

Table 8 Gastronomic inventory

\begin{tabular}{|l|l|l|}
\hline $\begin{array}{l}\text { Name of the } \\
\text { attraction } \\
\text { Traditional } \\
\text { holidays }\end{array}$ & Scheduled events & \multicolumn{1}{|c|}{$\begin{array}{l}\text { Type } \\
\text { cultural } \\
\text { festivals }\end{array}$} \\
\hline Picture & & \\
\hline
\end{tabular}

\begin{tabular}{|l|l|}
\hline $\begin{array}{l}\text { Rancho El } \\
\text { Refugio }\end{array}$ & Crafts \\
\hline Picture & $\begin{array}{l}14 \text { km from Santiago, in the sub- } \\
\text { delegation of San Dionisio. }\end{array}$ \\
\hline Location & $\begin{array}{l}\text { I work with the skins of animals of the } \\
\text { region such as cow, deer, snake for the } \\
\text { elaboration of saddles for horses, } \\
\text { belts, purses, hats, wallets, covers } \\
\text { among others. }\end{array}$ \\
\hline Characteristions
\end{tabular}

Table 9 Other inventories

\section{Based on the CFKE analysis, the following strategies were selected:}

\section{Short-term strategies}

1. Prepare signage for tourist places.

2. Positioning of the region as a tourism product, unifying the providers of services and products under a representative logo of the region

\section{Medium-term strategies}

1. Advise the interested party to manage it with federal support (support for women, lost funds, for SMEs, etc.

2. Make strategic alliances with travel agencies, hotels and tourism service providers.

\section{Long-term strategies}

1. Carry out national and international promotion. (videos, brochures, website).

2. Give training courses to interested parties to form competencies for the profile of tourism entrepreneurship and development. 


\section{Balanced Scorecard (BSC)}

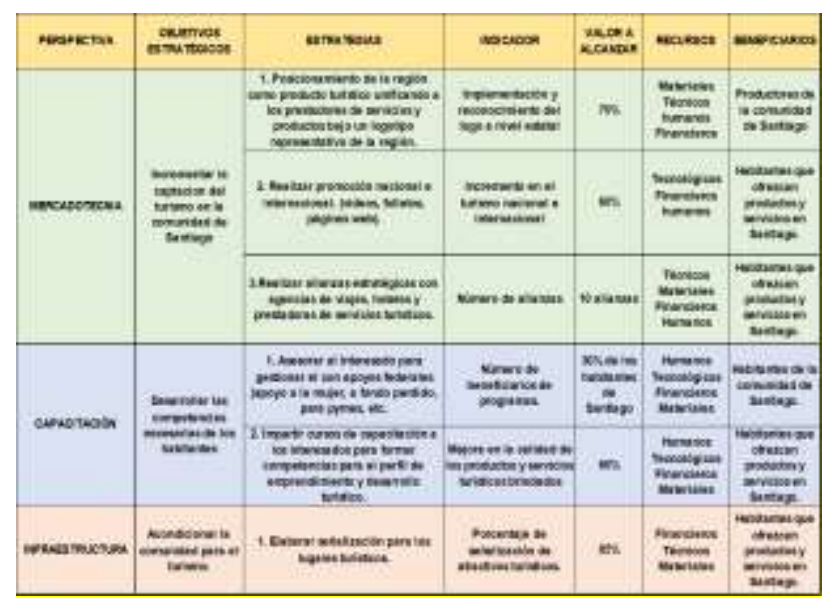

Table 10

\section{Conclusions}

In conclusion, we can say that Santiago and its surroundings have high potential to carry out activities that generate an economic income with which the people and their families of the same community of Santiago can benefit through its products and services. . However, it is the same people who lack the planning, organization and lack of knowledge to undertake and carry out said activities, also considering that most of them do not have the resources and means necessary to empower and carry out projects to that stay operational and have a positive impact on the community market, thus creating job opportunities for more people within the same community

Another aspect is that the few people who carry out or generate an activity that generates income do not have the necessary training and certifications to carry out, being able to improve the quality of either their products or services.

Also due to the little support that the government provides to the community, or which can only be seen in times of electoral campaigns, and later the same government allocates resources to other communities or other projects of less relevance or impact. You can also appreciate the ignorance of people to be able to lower economic support and the lack of communication between them to carry out the exploitation of said resources and the little support that is received from the government or the different agencies
Taking the previous results as an argument, it is necessary to implement tools to organize and structure the information in order to develop a strategic plan that serves as an instrument for the creation of a network of tourism products and services in the community of Santiago.

\section{References}

Anonimo. (15 de noviembre de 2019). Instituto Nacional de Estadistica y Geografia. Obtenido de INEGI http://www.inegi.org.mx

Badii, M. A. (2011). Nociones Introductorias de Muestreo Estadístico . Daeena:Internacional Journal off Good Conscience, 17.

Casal, F. M. (2002). Servicios turisticos diferenciados: animacion, turismo, aventura, turismo cultural, ecoturismo, turismo recreativo. Mexico: Trillas.

Chiavenato. (2011). Planeacion Estrategica y aplicaciones. Mexico: McGraw-Hill. 